\title{
Role of tumor cell senescence in non- professional phagocytosis and cell-in-cell structure formation
}

\author{
Dorian Gottwald ${ }^{1 \dagger}$, Florian Putz ${ }^{1 \dagger}$, Nora Hohmann ${ }^{1}$, Maike Büttner-Herold ${ }^{2}$, Markus Hecht ${ }^{1}$, Rainer Fietkau ${ }^{1}$ and \\ Luitpold Distel ${ }^{1 *}$ (D)
}

\begin{abstract}
Background: Non-professional phagocytosis is usually triggered by stimuli such as necrotic cell death. In tumor therapy, the tumors often disappear slowly and only long time after the end of therapy. Here, tumor therapy inactivates the cells by inducing senescence. Therefore, study focused whether senescence is a stimulus for nonprofessional phagocytosis or whether senescent cells themselves phagocytize non-professionally.

Results: Senescence was induced in cell lines by camptothecin and a phagocytosis assay was performed. In tissue of a cohort of 192 rectal cancer patients senescence and non-professional phagocytosis was studied by anti-histone H3K9me3 and anti-E-cadherin staining. Senescent fibroblasts and pancreas carcinoma cells phagocytize necrotic cells but are not phagocytized. In the tissue of rectal carcinoma, senescent cells can phagocytize and can be phagocytized. A high number of senescent cells and, at the same time, high numbers of non-professional phagocytizing cells in the rectal carcinoma tissue lead to an extremely unfavorable prognosis regarding overall survival.

Conclusion: Senescent cells can be non-professionally phagocytized and at the same time they can nonprofessionally phagocytize in vivo. In vitro experiments indicate that it is unlikely that senescence is a strong trigger for non-professional phagocytosis. Combined high rates of non-professional phagocytosis and high rates of senescence are an extremely poor prognostic factor for overall survival.
\end{abstract}

Keywords: Cell-in-cell, Non-professional phagocytosis, Senescence, Cannibalism, Entosis, Rectal cancer, Camptothecin, Prognostic factor and survival

\section{Background}

Radiation therapy of cancer achieves its therapeutic effect through the induction of different types of cell death. The predominant types of cell death are apoptosis and necrosis, which are also the most widely discussed types of cell death recognized in current morphological nomenclature [1].

\footnotetext{
* Correspondence: Luitpold.Distel@uk-erlangen.de

${ }^{\dagger}$ Dorian Gottwald and Florian Putz contributed equally to this work. 'Department of Radiation Oncology, Universitätsklinikum Erlangen, Friedrich-Alexander-Universität Erlangen-Nürnberg, D-91054 Erlangen, Germany

Full list of author information is available at the end of the article
}

Apoptotic and necrotic cell death as well as most other kinds of cell death mostly lead to a rapid elimination of cell remnants. In striking contrast, however, it is well known from radiotherapy that most malignancies do not resolve during multi-week fractionated radiation treatment. Indeed, most malignancies require several weeks after the end of treatment to show volumetric tumor regression in clinical and imaging assessment $[2,3]$. In rectal cancer for example, Habr-Gama et al. found a median time interval of 18.7 weeks from completion of radiotherapy to complete endoscopic clinical response [4]. An alternative route to tumor

C C The Author(s). 2020 Open Access This article is licensed under a Creative Commons Attribution 4.0 International License, which permits use, sharing, adaptation, distribution and reproduction in any medium or format, as long as you give appropriate credit to the original author(s) and the source, provide a link to the Creative Commons licence, and indicate if changes were made. The images or other third party material in this article are included in the article's Creative Commons licence, unless indicated otherwise in a credit line to the material. If material is not included in the article's Creative Commons licence and your intended use is not permitted by statutory regulation or exceeds the permitted use, you will need to obtain permission directly from the copyright holder. To view a copy of this licence, visit http://creativecommons.org/licenses/by/4.0/ The Creative Commons Public Domain Dedication waiver (http://creativecommons.org/publicdomain/zero/1.0/) applies to the data made available in this article, unless otherwise stated in a credit line to the data. 
inactivation is instead of initiating cell death, to induce non-proliferative cells by triggering so-called premature senescence [5]. It means that cancer cells initiate a programmed sequence of events leading to a phenotype of a stable and long-term loss of proliferative capacity, despite continued viability and metabolic activity [6]. Changes observed in senescent cells include the activation of the tumor suppressor network, morphological changes, altered chromatin structure and an altered spectrum of secreted factors $[7,8]$. Cancer therapy and especially radiochemotherapy usually causes senescence [9-11].

Senescent cells thus could be the reason for the delayed removal of cancer cells after RT. Senescent cells cause a pro-inflammatory response known as senescenceassociated secretory phenotype (SASP) $[12,13]$. This inflammation may clear the senescent cells by immunemediated phagocytosis [14, 15]. Another option to clear cells is the phagocytosis by non-professional phagocytes. It was shown that various normal tissue cells [16-19] and cancer cells [20-25] have the capability to engulf apoptotic, autophagic or necrotic cells. This leads to a cell-in-cell (CIC) phenotype and a subsequent digestion of the phagocytized cells. In cancers the frequently observed phenomenon of cell-in-cell structures by non-professional phagocytosis has also been referred to as "cell cannibalism" and describes the uptake and elimination of malignant cells by other cancer cells. Cell cannibalism is a very frequent finding in cancer [22, 26]. A so far not resolved question is whether senescent cells are cleared by non-professional phagocytes and if the increase of cell-in-cell structures and senescence in pathologic specimens are somehow related.

The aim was to study the involvement of senescence in cell-in-cell, either as a recipient cell or as an engulfing cell. We used a pancreatic carcinoma cell line and two primary fibroblast cell lines to act as non-professional phagocytes. It was studied whether senescent cells are preferred targets of non-professional phagocytosis or entotic cell death. In addition, using histologic samples from rectal cancer patients obtained prior to and after radiochemotherapy, the prevalence and prognostic significance of nonprofessional phagocytosis in rectal cancer as well as the association between tumor cell senescence and cell-in-cell structure formation were studied.

\section{Results}

Non-professional phagocytosis

Dead cells induced by heat were non-professionally phagocytized by living epithelial lung cells (BEAS2B). Cell death was induced by overheating to $56{ }^{\circ} \mathrm{C}$ for 45 min (Fig. 1a). The living cells adhered to the dead cells

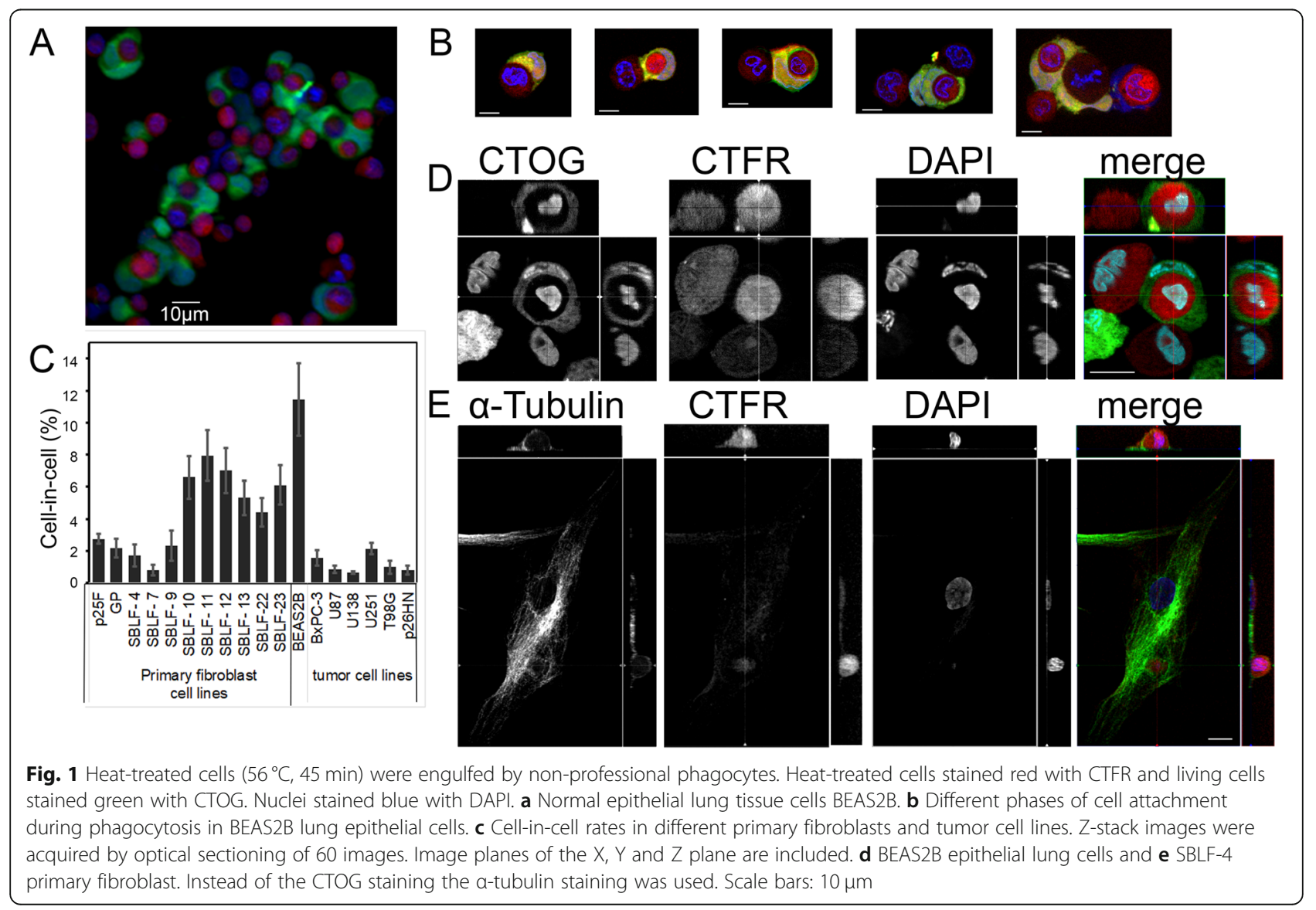


and phagocytized them within two to $10 \mathrm{~h}$ (Fig. 1b). Phagocytotic rates ranged from less than 0.65 to $11.5 \%$. Normal tissue cell lines (mean value $5.6 \%$ ) phagocytized more than tumor cell lines $(1.2 \%)(p=0.001)$ (Fig. 1c). In the process of phagocytosis, the overheated cell was completely engulfed by the living cell (Fig. 1d, e).

\section{Senescence in tumor and normal-tissue cell lines}

The aim was to study whether senescence is a trigger for non-professional phagocytosis observed for heat-induced cell death and whether senescent cells are being phagocytized by non-senescent cells. The chemotherapeutic agent camptothecin (CPT) was used to trigger senescence in BxPC-3 cells. After 6 days of incubation with $120 \mathrm{nM}$ or $200 \mathrm{nM}$ CPT cells were assessed for senescence induction by detection of high-mobility group AT-hook 2 (HMGA2) protein and Histone 3 trimethylated at the 9th lysine residue (H3K9me3) heterochromatic foci formation, flow cytometric $\beta$ galactosidase staining as well as the estimation of the nuclear size in both axes. A clear change of the staining pattern (Fig. 2a) and a distinct increase in nuclear size in both axes (Fig. 2b) was detected.

Additionally, the $\beta$-galactosidase activity was analyzed and a distinct increase up to day six by $120 \mathrm{nM} \mathrm{CPT}$ was found $(p<0.05)$ (Fig. 2c, d). Thus, the $120 \mathrm{nM} \mathrm{CPT}$ on day 6 induced a $\beta$-galactosidase+ activity in BxPC3+ cells of 42.7 (standard deviation $\pm 4.7 \%$ ), in SBLF-7 of $52.7 \pm 4.2 \%$ and in SBLF-4 of $67.1 \pm 6.0 \%$ (Fig. 2e). Cells with a high percentage of senescent cells on day 7 also had increased levels of Annexin $\mathrm{V}$ and 7Aminoactinomycin (7AAD) positivity (Fig. 2f). We selected the BxPC-3 cell line and the fibroblasts cell cultures SBL-F7 and SBLF-4 having $120 \mathrm{nM}$ CPT induced senescence rates of $78.0 \%$ (standard deviation $\pm 4.2 \%$ ), $74.1 \% \pm 7.2$ and $97.8 \% \pm 8.8$, respectively (Additional file 1: Figure 1).

Alternatively, the induction of senescence in BxPC-3 cells was studied using immunostaining (Fig. 3a-d). After treatment with $120 \mathrm{nM}$ campthothecin, the percentage of p21 staining as senescence marker increased from 19.9 to $80.1 \%(p=0.021)$. With $76.6 \%$ there were slightly less dead cells present compared to living cells (Fig. 3e) $(p=0.014)$. In the BxPC-3 cell line, the CIC rates of non-senescent cells and senescent cells were determined. $1.3 \%$ of p $21+$ senescent cells and $2.1 \%$ of non-senescent cells had at least one dead cell phagocyted $(p=0.043)$ (Fig. 3f).

\section{Association of cell-in-cell structure formation and senescence in tumor and normal-tissue cell lines}

Immunostaining was used to study non-professional phagocytosis of the three cell lines. Either cells were stained green or red by fluorescent live-cell stains
(Fig. 4a-c). H3K9me3 antibodies were used to identify senescence cells (Fig. 4d-f). Only H3K9me3-positive cells were counted, which have had phagocytized CTOGpositive cells. No CIC events were observed, suggesting that cells showing signs of premature senescence are not phagocytized in vitro by viable cells. Conversely, it was not observed that living cells or senescent cells phagocytized living cells. H3K9me3+ senescent cells were coincubated with CTOG+ necrotic cells and a similar high frequency of phagocytic event as for the viable cells $(0.95 \%)$ was found (Fig. 4g-j). It indicates that senescent cells are capable of phagocytosis at comparable frequencies to non-senescent cells.

\section{Cell-in-cell structures in clinical rectal cancer tissue samples}

The frequency and prognostic relevance of cell-in-cell structures and senescent cells was studied in a rectal cancer cohort that was treated with neoadjuvant radiochemotherapy (RCT). A total of 96 patients with Tissue Micro Array (TMA) samples of tumor biopsy ("biopsy"), obtained during pretreatment endoscopy, were analyzed. In addition, TMA samples from the resected tumor at 6 weeks post-RCT were used for analysis. TMAs from these surgical specimens were available in 146 patients from the tumor core "central tumor", in 97 patients in the tumor invasion zone ("invasive front") and in $167 \mathrm{pa}$ tients in surrounding normal tissue ("normal tissue"). The clinical and histological characteristics of the cohort are given in Table 1. Patients having pre-RCT biopsies, had a 5 -year overall survival of $69.8 \%$, a metastasis-free survival of $64.5 \%$ and a local recurrence-free survival of 70.1\%, respectively (Fig. 5a). Post-RCT patients had a 5year overall survival of $67.8 \%$, a metastasis-free survival of $57.8 \%$ and a local recurrence-free survival of $61.1 \%$, respectively (Fig. 5b). All TMAs were stained by antibodies, for anti-H3K9me3 (blue, nuclear) to detect senescent cells and for anti-E-Cadherin (red, membranous) to detect cell-in-cell structures (Fig. 5c, d).

\section{Prevalence of senescence and cell-in-cell structures in different tumor compartments}

The median number of epithelial senescent cells $/ \mathrm{mm}^{2}$ was highest in the central tumor area $\left(560\right.$ cells $\left./ \mathrm{mm}^{2}\right)$ followed by normal tissue $\left(494\right.$ cells $\left./ \mathrm{mm}^{2}\right)$. In the biopsies and invasive front numbers of senescent cells were similar (360 cells $/ \mathrm{mm}^{2}$ vs. 369 cells $/ \mathrm{mm}^{2}$ ), respectively (Fig. 5e). The mean numbers of epithelial cell-in-cell structures $/ \mathrm{mm}^{2}$ were most frequent in the invasive front (1.0 cell-in-cell $\left./ \mathrm{mm}^{2}\right)$ followed by the central tumor region $\left(0.72\right.$ cell-in-cell $\left./ \mathrm{mm}^{2}\right)$ and biopsies $(0.56$ cell-incell $\left./ \mathrm{mm}^{2}\right)$. In normal tissue cell-in-cell phenomena were least common (0.08 cell-in-cell/ $\left.\mathrm{mm}^{2}\right)$ (Fig. 5f). 


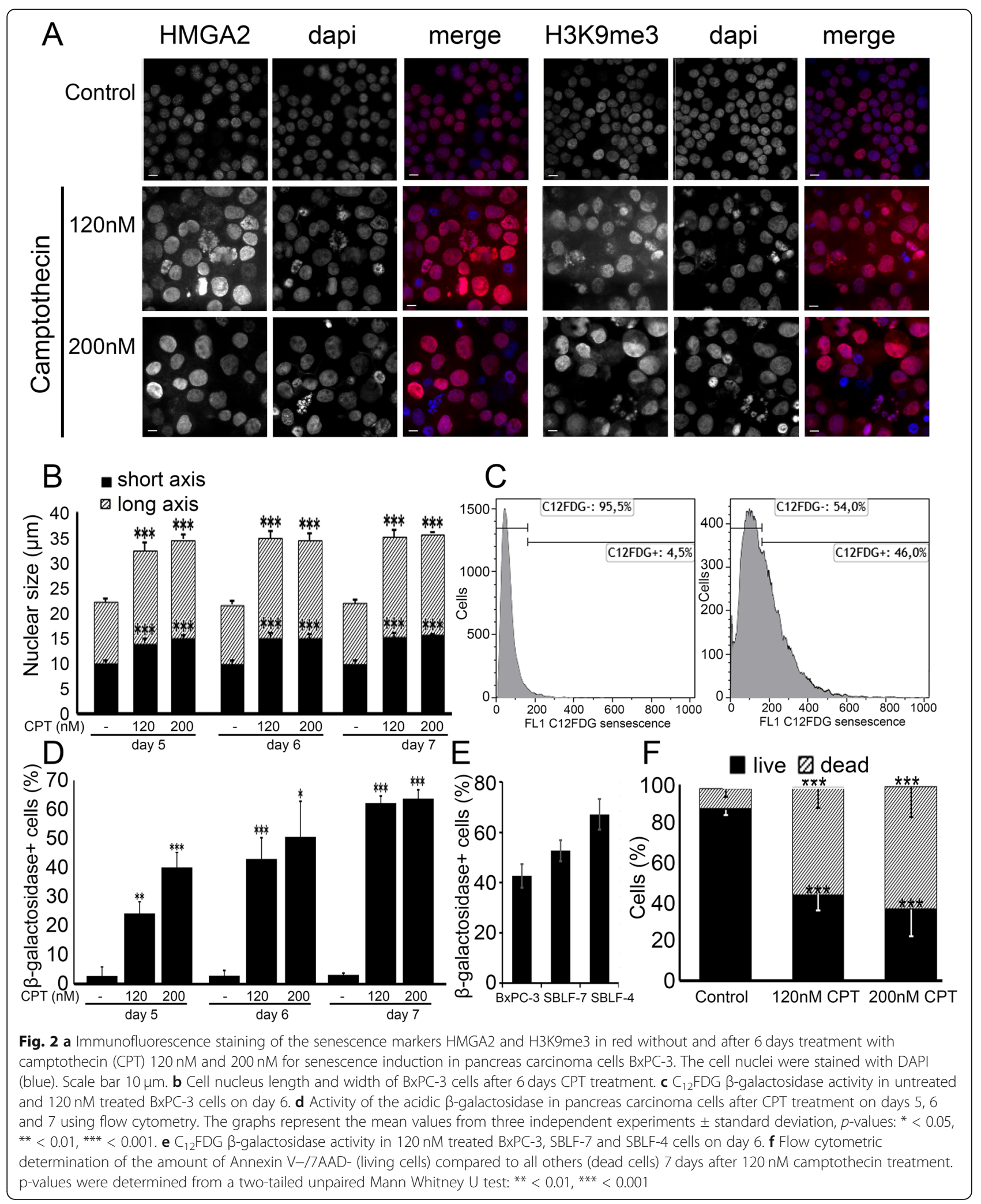




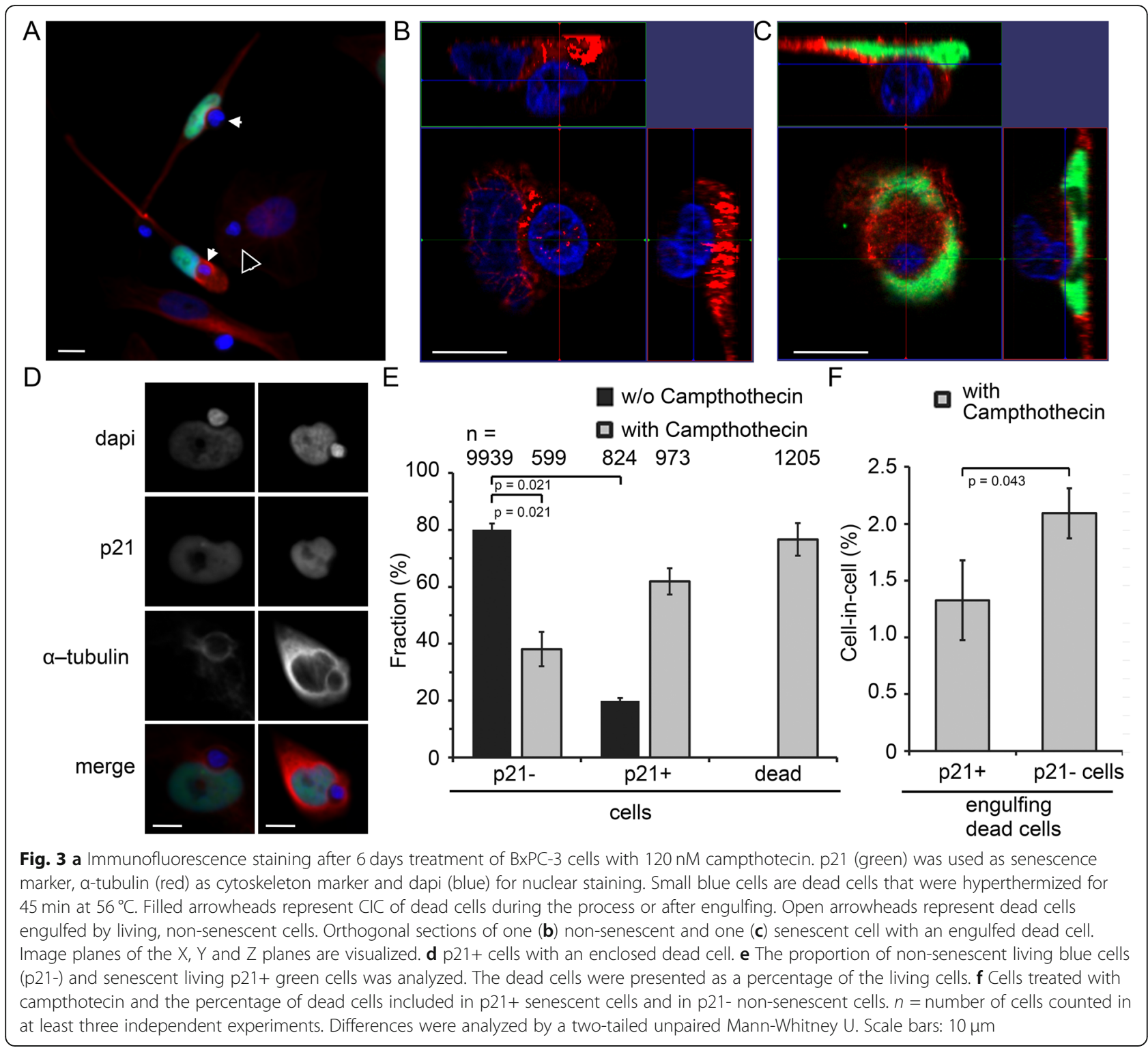

\section{Prognostic significance of cell-in-cell and senescence} rates in clinical rectal carcinoma tissue samples

The prognostic relevance of senescent cells and cell-incell structures for the following outcomes was analyzed: overall survival, metastasis-free survival, local recurrence-free survival and tumor-specific survival. For each outcome the cut-off values were determined by receiver operating characteristic (ROC) analysis resulting in specific cut off values for each individual analysis. Overall survival was clearly favorable for patients with a low number of senescent cells in pretreatment biopsies (5-year overall survival, $78.5 \%$ v. $61.2 \%, p=0.045$ ) (Fig. 6a) as well as central tumor areas $(80 \%$ v. $76.8 \%$, $p=0.043$ ) (Fig. 6b).

Senescent cells in the invasive tumor front or normal tissue had no prognostic relevance, however (Fig. 6c, d).
Cell-in-cell in biopsies were not significantly associated with prognosis. Patients having less than three cell-in-cell structures $/ \mathrm{mm}^{2}$ in the central tumor had a clearly improved overall survival $(73.3 \%$ v. $46.9 \%, p=0.001)$ (Fig. 6e, $\mathrm{f}, \mathrm{g})$. Patients having less than 0.2 cell-in-cell structure/ $\mathrm{mm}^{2}$ in their normal tissue (Fig. 6h) also had a distinctly improved prognosis $(71.8 \%$ v. $56.0 \%, p=0.042)$.

Moreover, low numbers of senescent cells in the biopsies $(86.3 \%$ v. $74.4 \%, p=0.046)$ and low numbers of cellin-cell structures $(80.4 \%$ v. $65.7 \%, p=0.015)$ and senescent cells $(89.0 \%$ v. $70.6 \%, p=0.014)$ in the central tumor area were associated with improved tumorspecific survival (Additional file 2: Figure 2). High numbers of senescent cells in the invasive tumor front were a predictor of a favorable local recurrence-free survival (73.3\% v. $49.3 \%, p=0.024$, Additional file 3: Figure 3). 


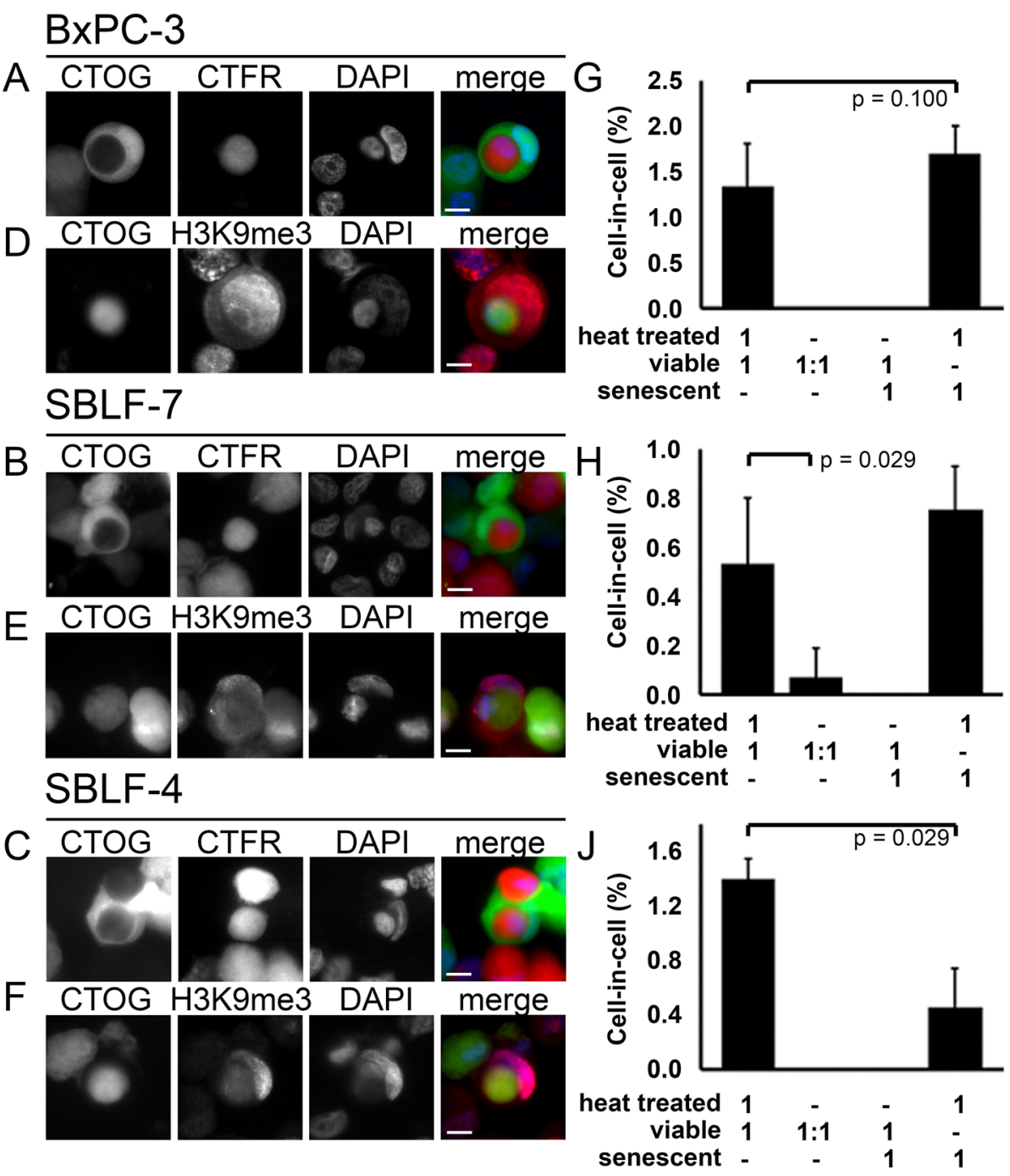

Fig. 4 Representative microscopic images of typical cell-in-cell structures in phagocytosis experiments with (a, d) pancreas carcinoma cell line (BxPC-3) and fibroblast cell lines (b, e) (SBLF-7) and (c, f) (SBLF-4). Viable CTOG-stained (green) cell, which completely encloses a hyperthermiadamaged, CTFR-stained (red) cell (a-c). Senescent H3K9me3-stained (red) cells that completely enclose a hyperthermia-damaged CTOG-stained (green) cell (d-f). Cell nuclei were stained with DAPI (blue). Scale bars $10 \mu \mathrm{m}$ (40x objective). In bar charts (g), (h) and (j) the cell-in-cell rates occurring in the respective cell lines on the left were shown for different combinations of senescent, living and heat-treated dead cells as indicated

Patients with high senescent cell rates in biopsies $(53.7 \%$ v. $75.6 \%, p=0.021)$ and central tumor $(50.3 \%$ v. $73.7 \%$, $p=0.013)$ developed metastatic disease significantly more frequently than patients with low rates (Additional file 4: Figure 4).

\section{Association of senescence with cell-in-cell structures in rectal cancer tissue samples}

Each observed cell-in-cell structure $(n=670)$ was photographed and was analyzed according to whether the engulfed and/or phagocytotic cell was senescent (Fig. 7a-e).

Senescent cells were observed in $67 \%$ of all cell-in-cell structures. Most frequently senescent cells were engulfed by a non-senescent cell (39.4\% of all cell-in-cell structures, Fig. 7b, f), followed by both participating cells not being senescent (33\%, Fig. 7c, f) and both cells being senescent (18.4\%, Fig. 7d, f). Non-senescent cells only rarely were engulfed by senescent host cells (9.3\%, Fig. $7 \mathrm{e}, \mathrm{f})$. This association was highly significant: Senescent cells were significantly more frequently internalized in cell-in-cell structures than constituting the external host cell (57.8\% vs. $27.6 \%, p<0.001$ Fisher's exact test).

Combination of cell-in-cell and senescence rates as prognostic factors

In addition, the prognostic relevance of combined rates of senescence and cell-in-cell phenomena was studied. 
Table 1 Clinical characteristics of rectal cancer patients

\begin{tabular}{|c|c|c|c|}
\hline & & $\begin{array}{l}\text { Pre RCT biopsies } \\
\text { n (\%) }\end{array}$ & $\begin{array}{l}\text { Post RCT tumor resections } \\
\text { n (\%) }\end{array}$ \\
\hline Variable & All patients & $96(100)$ & $146(100)$ \\
\hline \multirow[t]{2}{*}{ Gender } & male & $63(65.6)$ & $110(75.3)$ \\
\hline & female & $33(34.4)$ & $36(24.7)$ \\
\hline Age at diagnosis & mean & 64 y (35-93 y) & 63 y (33-84 y) \\
\hline \multirow[t]{4}{*}{ UICC stage } & I & $7(7.3)$ & $8(5.5)$ \\
\hline & $\|$ & $24(25)$ & $34(23.3)$ \\
\hline & III & $52(54.2)$ & $81(55.5)$ \\
\hline & IV & $13(13.5)$ & $23(15.8)$ \\
\hline \multirow[t]{3}{*}{ Grading } & G1 & $4(4.2)$ & $3(2.1)$ \\
\hline & $\mathrm{G} 2$ & $77(80.2)$ & $116(79.5)$ \\
\hline & G3 & 15 (15.6) & $27(18.5)$ \\
\hline \multirow[t]{4}{*}{ T stage } & $\mathrm{T} 1$ & $4(4,2)$ & $3(2.1)$ \\
\hline & $\mathrm{T} 2$ & $13(13.5)$ & $18(12.3)$ \\
\hline & T3 & $72(75)$ & $105(71.9)$ \\
\hline & T4 & $7(7.6)$ & $20(13.7)$ \\
\hline \multirow[t]{4}{*}{ N stage } & No & $32(33.3)$ & $48(32.9)$ \\
\hline & N1 & $64(66.7)$ & $98(67.1)$ \\
\hline & N2 & $0(0)$ & $0(0)$ \\
\hline & N3 & $0(0)$ & $0(0)$ \\
\hline \multirow[t]{2}{*}{ M stage } & Mo & $83(86.5)$ & $123(84.2)$ \\
\hline & M1 & $13(13.5)$ & $23(15.8)$ \\
\hline \multirow[t]{4}{*}{ Chemotherapy } & 5-FU mono & 38 (39.6) & $53(36.3)$ \\
\hline & Oxaliplatin - 5-FU & $42(43.8)$ & $76(52.1)$ \\
\hline & other 5-FU-combinations & $7(7.3)$ & $5(3.4)$ \\
\hline & others & $9(9.4)$ & $12(8.2)$ \\
\hline \multirow[t]{5}{*}{ Dworak regression grade } & 0 & $1(1)$ & $3(2.1)$ \\
\hline & 1 & $8(8.3)$ & $9(6.2)$ \\
\hline & 2 & $22(22.9)$ & $55(37.7)$ \\
\hline & 3 & $53(55.2)$ & $79(54.1)$ \\
\hline & 4 & $12(12.5)$ & $0(0)$ \\
\hline
\end{tabular}

The combined group having high numbers of senescent cells and high cell-in-cell $/ \mathrm{mm}^{2}$ rates was associated with a poor overall survival (Fig. 8a-d).

Therefore, high cell-in-cell and high senescent cell rates were compared to all others (Fig. 8e-f). Patients with high senescent and cell-in-cell rates in the central tumor had a particularly unfavorable prognosis $(73.3 \% \mathrm{v}$. $46.9 \%)(p<0.001$, Fig. 8f). Similarly, in the normal tissue patients with "high-high" rates showed an unfavorable prognosis $(71.7 \%$ v. $46.7 \%)$ ( $p=0.011$ ) (Fig. 8 h). Univariate and multivariate Cox's regression analyses for overall survival were performed including clinical prognosticators and TNM stage. M stage $(p<0.001)$ and combined high cell-in-cell $/ \mathrm{mm}^{2}$ with high senescence $/ \mathrm{mm}^{2}$ in the tumor post RCT ( $p=0.001)$ were independent prognostic factors for overall survival in multivariate analysis (Table 2).

\section{Discussion}

Cell lines with induced senescence were not phagocytized in vitro, but were able to phagocytise other cells very effectively. In contrast, naturally occurring senescent cells in rectal cancer tissue samples were phagocytized. Only $27.6 \%$ of phagocytic cells were senescent, whereas $57.8 \%$ of phagocytized cells presented a senescent state. Low cell-in-cell rates were associated with favorable overall survival. A high number of senescent cells and at the same time a high number of cell-in-cell 


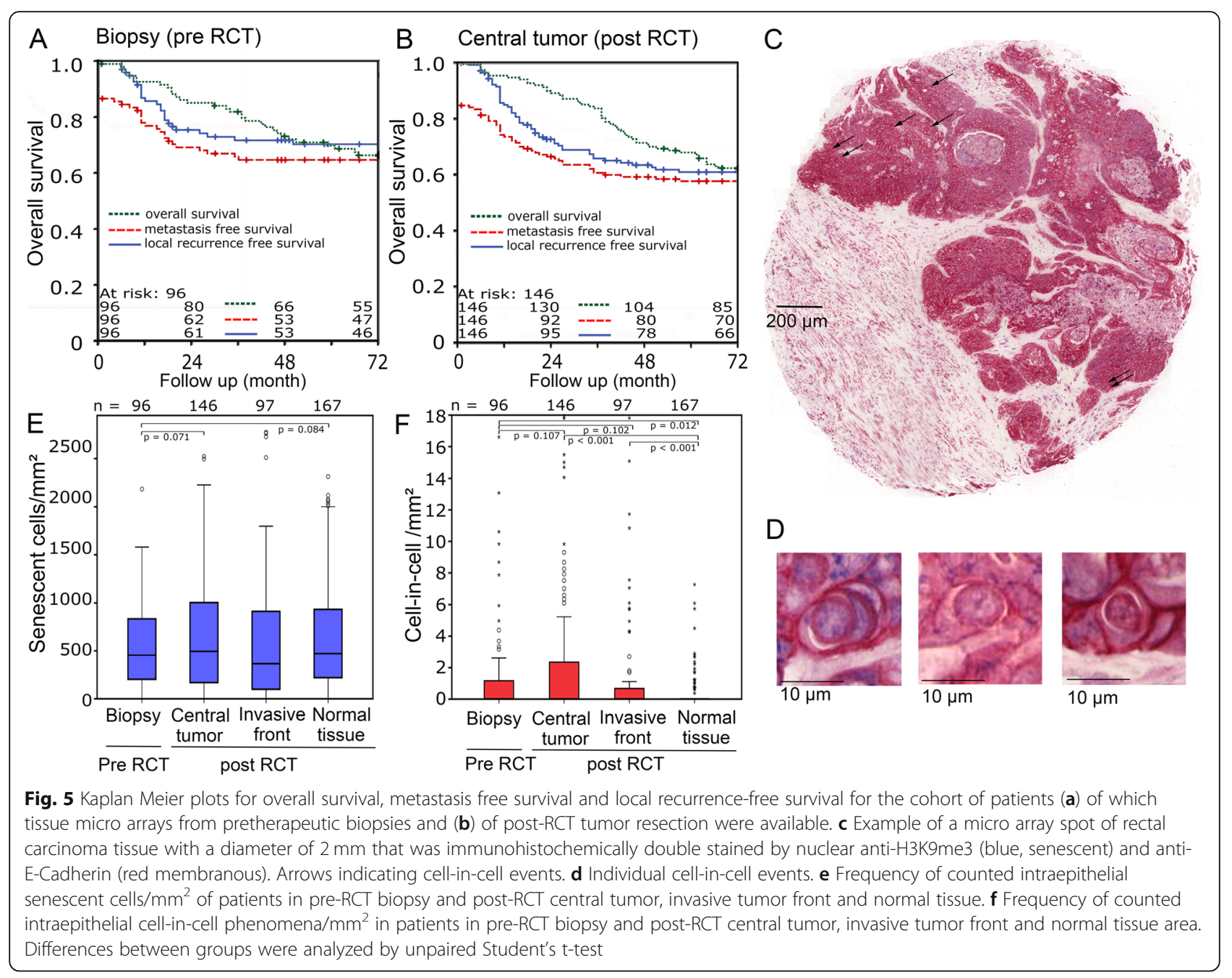

structures in the tissue lead to an extremely unfavorable prognosis regarding overall survival.

The question whether senescent cells are a stimulus for phagocytosis has been answered contradictory. However, the results of the cellular in vitro investigations were unmistakable. In all three studied cell lines absolutely no senescent cells had been phagocytized. Since clear experimental conditions are given and a high percentage of senescent cells were available and no phagocytosis occurred at all, this strongly suggests that senescence is not a trigger for phagocytosis. In tissue, the properties of the cells are not so definite. Even if the cells have a senescent phenotype, they may have suffered a necrotic death afterwards. In particular, radiochemotherapy involves daily radiation for about 6 weeks and additional chemotherapy. In this way cells can be driven into senescence [27] and then these cells can be damaged even further so that they die as a consequence [28]. Death of senescent cells is mainly necrotic or other non programmed death [29, 30]. Therefore, the phagocytized cells could also be necrotically dead senescent cells. Since necrosis is a strong trigger for phagocytosis $[19,31]$, it can lead to subsequent engulfment of the senescent cells that have died necrotically. Necrotic cells cannot actively penetrate living cells but are actively ingested by living cells. An alternative explanation could be entosis, in which one cell actively penetrates another cell and causes its own uptake in the recipient cell [32]. It is thinkable that the observed cell-in-cell structures were formed by entosis and that this mechanism is applied preferentially by senescent cells. However, the experimental setup did not allow to assess this.

Another interesting issue is that heat-induced necrosis is a very strong trigger of non-professional phagocytosis. Sixty percent of cells treated with camptothecin were identified as dead in the Annexin V/7AAD assay. Astonishingly, however, in contrast to the cells killed at $56^{\circ} \mathrm{C}$, they were not phagocytized. This indicates that a difference exists that inhibits cells killed by camptothecin to be non-professionally phagocytized and thus prevents cell-in-cell phenomena. Additionally, this observation 


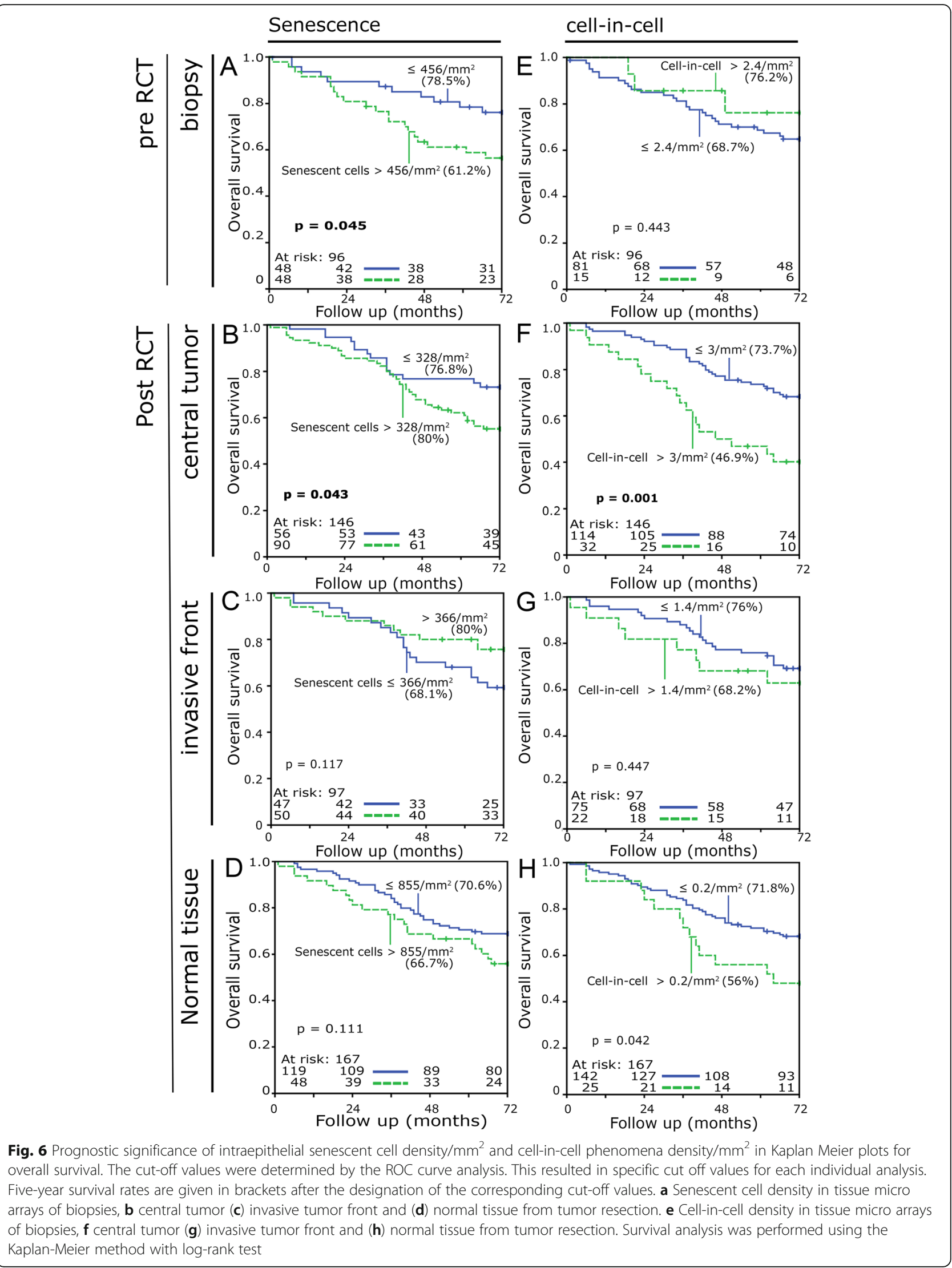



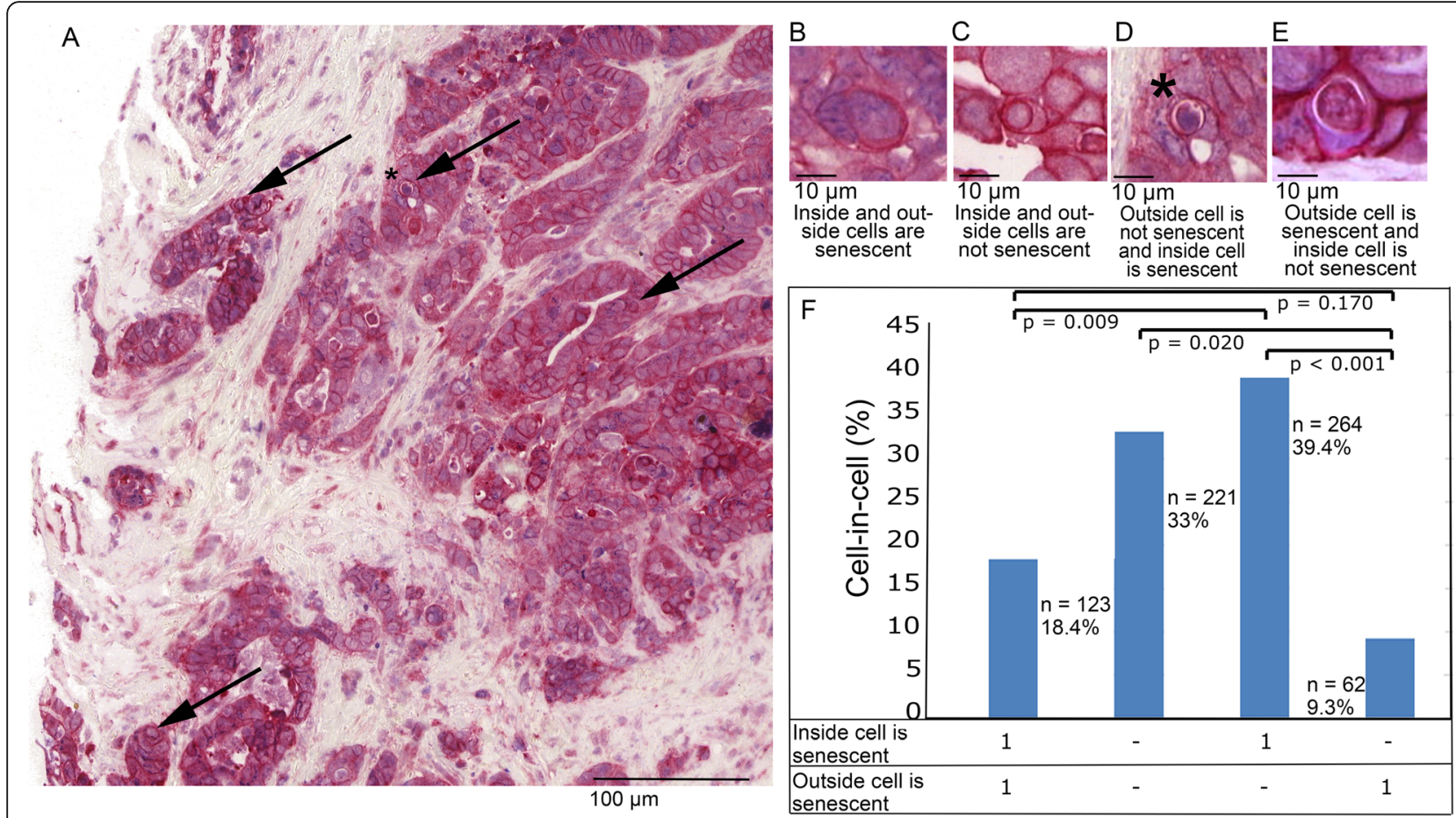

Fig. 7 a Part of a TMA immunohistochemical double stained for senescence by nuclear anti-H3K9me3 (blue) and membranous anti-E-Cadherin (red) in rectal cancer. Arrows indicating cell-in-cell events. Zoomed images of the tissue micro array, $\mathbf{b}$ a cell-in-cell event in which both involved cells are senescent, $\mathbf{c}$ a cell-in-cell event in which both involved cells are not senescent, $\mathbf{d}$ engulfed cell is senescent (asterisk marks the cell in the tissue micro array) and (e) a cell-in-cell event in which only the engulfing cell is senescent. $\mathbf{f}$ Distribution of senescence in the engulfing and in the engulfed cell in all observed cell-in-cell events. Differences were analyzed by the Student's t-test

indicates that senescence per se is not a distinct trigger of non-professional phagocytosis.

In general cell-in-cell structures are found both in normal tissue [31] and in tumor tissue [33]. A high rate of cell-in-cell structures in tumor tissue is a negative prognostic factor for example in breast carcinoma [20, 34], metastasis of melanoma [24], cytology of bladder cancer [35], head and neck cancer [25, 36], rectal cancer [25], oral squamous cell carcinoma [37] and lung adenocarcinoma [38]. In contrast, an increased incidence of homotypic cell cannibalism in ductal adenocarcinoma of the pancreas was associated with decreased metastatic potential and consequently was a positive prognostic factor [21]. Additionally, adherent wild-type cells can act efficiently as entotic hosts, suggesting that normal epithelia may engulf and kill aberrantly dividing neighboring cells [39]. High cell-in-cell rates and high senescence rates are prognostically unfavorable markers for rectal cancer patients in this study. Senescence occurred more frequently after RCT in the central tumor tissue. Cell-in-cell structures were also found more frequently in the central tumor. This study shows that high cell-in-cell rates in rectal carcinomas can be considered as an adverse prognostic marker for survival. A reason might be that the phagocytosis leads to an increased supply of substances to the tumor cells [40-42]. In addition, selection of particularly malignant tumor cells is likely to occur by competition, in which the ability to engulf neighboring cells could constitute a distinct advantage [43]. The poorer survival for patients with high senescence values could be explained by the senescenceassociated secretory phenotype [44-47]. There could be an association between cell-in-cell structures and senescence. Hints for this are that senescent cell lines like fibroblasts and pancreas carcinoma cells phagocytize in vitro and that in vivo in $67 \%$ of cellin-cell structures in rectal cancer TMAs senescent cells are involved. In the tissue of rectal cancer mainly senescent cells are phagocytized, but they can also phagocytize. The extremely poor survival of the subgroup with combined high senescence rates and high cell-in-cell rates is impressive. It was an independent marker for dramatically worse overall survival in rectal cancer patients. Prognostic markers are important for accurately individualizing therapies for rectal cancer patients, thereby reducing long-term costs and patient suffering [48, 49]. Given the strong prognostic significance in this investigation for rectal 


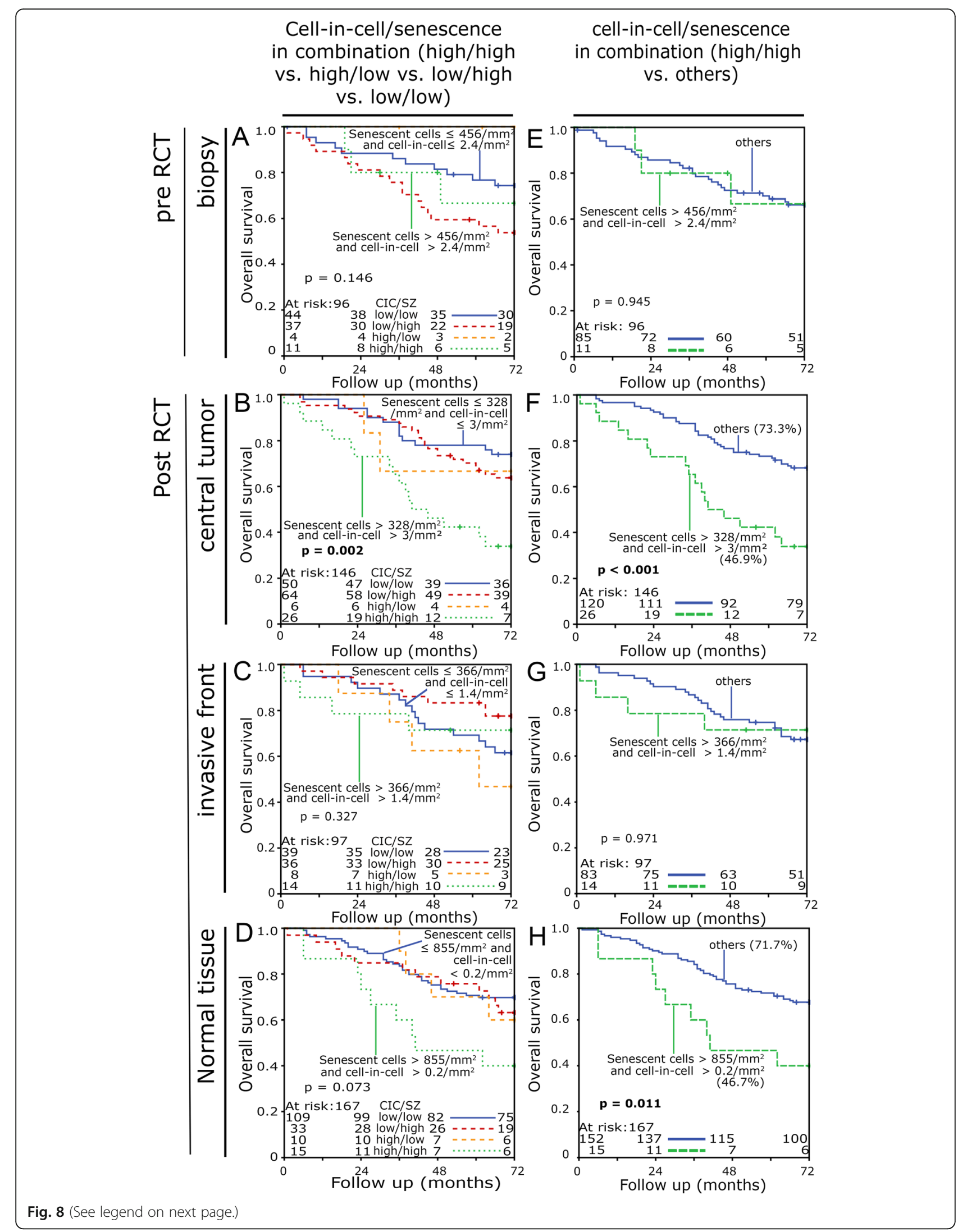


(See figure on previous page.)

Fig. 8 Kaplan Meier plots for overall survival of intraepithelial senescent cell density $/ \mathrm{mm}^{2}$ and cell-in-cell phenomena density $/ \mathrm{mm} \mathrm{m}^{2}$. The cut-off values were determined by the ROC curve analysis. This resulted in specific cut off values for each individual analysis. The five-year survival rate is given in brackets after the designation of the corresponding cut-off values. All graphs in the left column show high and/or low rates of senescent cells combined with high and/or low cell-in-cell events. a biopsies. $\mathbf{b}$ central tumor, $\mathbf{c}$ invasive tumor front and $\mathbf{d}$ normal tissue from the tumor resection. The graphs in the right column compare high senescence and high cell-in-cell rates to all other combinations. e biopsies. $\mathbf{f}$ central tumor, $\mathbf{g}$ invasive front and $\mathbf{h}$ the normal tissue from the tumor resection. Five-year survival rate is shown in brackets (f) and (h). Statistical significance was checked by the log-rank test

cancer patients, additional studies on cell-in-cell structures and senescence are clearly warranted. We would also have liked to study non-professional phagocytosis in normal tissue. However, in these tissues the CIC rates are extremely low [31] and accordingly the events with senescence are much lower. In the tumor surrounding normal tissue of TMAs we did find only very little CICs in this study and therefore could not investigate senescence involvement in non-professional phagocytosis. Therefore it was not possible to investigate the significance of senescence for CIC in normal tissue. A further limitation is that the cell experiments were only performed with heat and camptothecin treatment. In contrast, the patients were treated with radiochemotherapy. However, it was not our primary aim to perform the same treatment on cells and patients, but to induce senescence and to study senescence as a trigger for non-professional phagocytosis.

\section{Conclusion}

Senescent cells can be non-professionally phagocytized and at the same time they can non-professionally phagocytize in vivo. In vitro experiments indicate that it is unlikely that senescence is a strong trigger for non-professional phagocytosis. Combined high rates of non-professional phagocytosis and high rates of senescence are an extremely poor prognostic factor for overall survival.

\section{Material and methods \\ Cell cultures}

Three different cell lines were studied in vitro for senescence and sixteen cell lines for cell-in-cell structures. Cancer cells were pancreatic adenocarcinoma cells BxPC-3, glioblastoma cells U87, U138, U251 and T98G (American Type Culture Collection) and head and neck cancer cells HN-p26. Primary fibroblast cell lines p26F, SBLF-4, - 7, - 9, - 10, - 11, - 12, - 13, - 22, - 23 were each derived from young Caucasians. Human bronchial epithelial cells (BEAS-2B) were obtained from the British Sigma/Public Health Consortium. BxPC-3 cells were cultured in RPMI-1640 medium (Life Technologies GmbH, Darmstadt, Germany) and fibroblast cell lines in F12 medium (Life Technologies $\mathrm{GmbH}$, Darmstadt, Germany). Fetal calf serum, penicillin/streptomycin, glutamine and non-essential amino acids were added in different concentrations for each culture. The cells were cultured in at $37^{\circ} \mathrm{C}, 5 \% \mathrm{CO}_{2}$ and $95 \%$ humidity.

\section{Staining and immunofluorescence}

Senescence was determined either by flow cytometry or immunostaining as two independent methods. For the flow cytometric analysis, cells were incubated for $30 \mathrm{~min}$ in Bafilomycin $\mathrm{A} 1$ and afterwards $\mathrm{C}_{12} \mathrm{FDG}$ (Invitrogen, Auckland, New Zealand) was added for $60 \mathrm{~min}$ at $37^{\circ} \mathrm{C}$. For senescence analysis by immunostaining anti-H3K9me3 (Millipore, Darmstadt, Germany), anti-HMGA2 and p21 (Cell

Table 2 Univariate and multivariate analysis of overall survival according to Cox's proportional hazards model

\begin{tabular}{|c|c|c|c|c|c|c|}
\hline \multirow{2}{*}{$\begin{array}{l}\text { Rectal cancer } \\
\text { Variable }\end{array}$} & \multicolumn{3}{|c|}{ Univariate analysis } & \multicolumn{3}{|c|}{ Multivariate analysis } \\
\hline & $\begin{array}{l}\text { Hazard } \\
\text { ratio }\end{array}$ & 95\% C.I. & $p$ & Hazard ratio & $95 \%$ C.I. & $p$ \\
\hline T stage (T4 $[n=21]$ v. T1/T2/T3 $[n=121])$ & 0.596 & $0.272-1.306$ & 0.196 & 0.555 & $0.254-1.213$ & 0.140 \\
\hline $\mathrm{N}$ stage $(\mathrm{N}+[n=101]$ v. N0 $[n=41])$ & 0.732 & $0.4-1.337$ & 0.309 & 0.777 & $0.433-1.395$ & 0.398 \\
\hline M stage $(M+[n=23]$ v. M0 $[n=119])$ & 5.233 & $2.682-10.208$ & $<0.001$ & 4.495 & $2.469-8.183$ & $<0.001$ \\
\hline Grading $(3+4[n=27]$ v. $1+2[n=115])$ & 1.329 & $0.674-2.619$ & 0.411 & - & - & - \\
\hline Gender (female $[n=34]$ v. male $[n=108]$ ) & 0.796 & $0.416-1.522$ & 0.491 & - & - & - \\
\hline $\begin{array}{l}\text { Age }(>58 \text { years }[n=72] \vee .<58 \text { years } \\
[n=70])\end{array}$ & 1.772 & $1.002-3.132$ & 0.049 & 1.635 & $0.942-2.839$ & 0.081 \\
\hline $\begin{array}{l}\text { Cell-in-cell }>3 / \mathrm{mm}^{2}[n=31] \text { v. } \leq 3 / \mathrm{mm}^{2} \\
{[n=111]}\end{array}$ & 1.237 & $0.617-2.477$ & 0.549 & - & - & - \\
\hline Senescence $>328 / \mathrm{mm}^{2}[n=89]$ v. $\leq 328 / \mathrm{mm}^{2}[n=53]$ & 0.895 & $0.116-6.928$ & 0.915 & - & - & - \\
\hline Cell-in-cell $>3 / \mathrm{mm}^{2}$ and senescence $>328 / \mathrm{mm}^{2}[n=26]$ v. others $[n=116]$ & 2.849 & $0.332-24.434$ & 0.340 & 2.623 & $1.46-4.713$ & 0.001 \\
\hline
\end{tabular}


Signaling, Leiden, Netherlands) antibodies were used. Cytoskeleton was stained by $\alpha$-tubulin (Abcam, Cambridge, UK). Secondary antibodies were Alexa 488 chicken anti mouse or Alexa 594 chicken anti rabbit (Molecular Probes, Darmstadt, Germany). Phagocytosis experiments were performed using CellTrace Oregon Green (CTOG) (Invitrogen, Auckland New Zealand) for the living cells and CellTrace Far Red (CTFR) (Invitrogen, Auckland, New Zealand) for heat $\left(56^{\circ} \mathrm{C}\right)$ for camptothecin treated cells. Cell nuclei were stained by DAPI (Roche, GrenzachWyhlen, Germany) and slides were mounted using Vectashield (Vector Laboratories Inc., Burlingame, USA). Cell images were acquired by a Zeiss Axio Plan 2 fluorescence microscope (Zeiss, Göttingen, Germany). Nuclear size was analyzed with Biomas software (MSAB, Erlangen, Germany).

\section{Necrosis, senescence induction and non-professional phagocytosis}

Senescence was induced in cells by 120 and $200 \mathrm{nM}$ camptothecin for up to 7 days. Necrosis was induced by heating cells in a hyperthermic bath at $56^{\circ} \mathrm{C}$ for $45 \mathrm{~min}$. Cell death was analyzed by flow cytometry using the Annexin V-APC and 7AAD staining. The portion of $\beta$ galactosidase positive, living and necrotic cells were analyzed by flow cytometry (Gallios Flow Cytometer, Beckman Coulter, Fullerton, USA). Non-professional phagocytosis was studied by coincubating the same number of red and green cells for $4 \mathrm{~h}$. Homotypic phagocytosis experiments were always performed. The living cells and the dead cells in one experiment always came from the same cell line. For the phagocytosis trials the following cell mixtures were used: Vital green cells/ heat-treated red cells, vital green cells/senescent red cells, senescent red cells/heat-treated green cells, vital green cells/vital red cells. Slides were scanned with a fluorescence microscope at 400x magnification (Carl Zeiss Microscopy, Göttingen, Germany) and Metafer4 as software (Metasystems, Altlußheim, Germany). At least 1000 vital cells were counted to calculate the cell-in-cell rates. In case of cell-in-cell rates of less than $1 \%$ a total of 3000 viable cells were counted.

\section{Human specimens, tissue micro arrays and immunohistochemical staining}

The frequency and prognostic relevance of cell-in-cell structures and senescent cells were studied in a cohort of 192 rectal cancer patients that received neoadjuvant radiochemotherapy (RCT). All samples were processed into tissue microarrays (TMAs) of $2 \mathrm{~mm}$ core diameter. Clinical data were obtained from the Erlangen Tumor Centre Database and from patient's records (Table 1).

The average age was 64 and 63 years for pre-RCT and post-RCT specimens, respectively. The samples named "biopsies" $(n=96)$ were collected 6 weeks prior to RCT. Concurrent chemotherapy most frequently consisted of 5-fluorouracil/oxaliplatin. A post-treatment Dworak tumor regression score of grade 3 was achieved in most cases $(n=54.1 \%)$. Six weeks after the end of neoadjuvant RCT, patients had surgical tumor resection as part of routine clinical treatment $(n=146)$. The neoadjuvant radiochemotherapy and the time intervals correspond to the standard of treatments. Samples from the surgical specimen were taken from the "central tumor" region, the "invasive front" as well as surrounding "normal tissue". Immunohistochemical staining were performed on formaldehyde-fixed paraffin embedded tissue microarrays. Tissue sections were dewaxed. The antigens were damasked using target removal solutions pH 6 (TRS6, Dako Cytomation) in a steam cooker. Anti-E-cadherin (BD, Heidelberg, Germany) was used to visualize cell membranes by an alkaline-phosphatase-labeled polymer kit (Zytochem-Plus AP-PolymerKit, Zytomed Systems, Berlin, Germany) and a fast-red color reaction (SigmaAldrich, Deisenhofen, Germany). Senescent cells were detected by anti-H3K9me3 antibodies and a fast-blue color reaction (Sigma-Aldrich, Deisenhofen, Germany).

TMA Slides were scanned with a microscope at 200x magnification (Carl Zeiss Microscopy, Göttingen, Germany) using Metafer4 software (Metasystems, Altlußheim, Germany). Intraepithelial and stromal areas of each TMA spot were identified by the image processing software Biomas. The senescent cells and cell-in-cell structures were manually selected. Biomas software recorded the counts in the intraepithelial area per $\mathrm{mm}^{2}$. Every cell-in-cell structure was photographed and stored. Cells were regarded as senescent, when their nuclei stained positive for H3K9me3. Cell-in-cell structures were defined as complete enclosure of an inner cell by the membrane of an outer cell, a round nucleus of the inner cell and a semilunar enclosing by the nucleus of the outer cell.

Survival data were censored to 72 months to avoid dilution of data by untraceable drop-out of individual study participants. A corresponding cut-off was determined by a ROC curve analysis. Local failure-free survival, metastasis-free-survival, tumor-specific survival and overall survival were determined using the Kaplan Meier method and the log rank test. Univariate and multivariate Cox regression analysis for overall survival was performed. Age, gender, TNM stage, grading, high cell-in-cell counts $/ \mathrm{mm}^{2}$, high senescence counts $/ \mathrm{mm}^{2}$ and the combination of high cell-in-cell and high senescence counts $/ \mathrm{mm}^{2}$ were evaluated.

\section{Statistical analysis}

IBM SPSS Statistics version 21 (IBM Corp, Armonk, NY, USA) was used for statistical analysis. Data were expressed as mean \pm standard deviation (SD). Differences between 
individual groups were analyzed by Mann-Whitney U, Fisher's exact test or Student's t-test. Survival curves for overall survival, tumor specific survival, local recurrence free survival and metastasis free survival were plotted using the Kaplan-Meier method and compared with the log-rank test. Optimal cut-off points for survival analysis between low or high density groups of senescent cells or cell-in-cell events were determined through receiver operating characteristic (ROC) curve analysis. Cox proportional hazards model was used to calculate hazard ratios of cell-in-cell rates, senescence rates and clinicopathological characteristics. Covariates with $p<0.35$ in univariate analysis were included in multivariate Cox regression. The proportional hazards assumption was tested by visual inspection of log minus log curves and was found to be satisfactory for all multivariate covariates. $p$-values $<0.05$ were considered to be statistically significant.

\section{Supplementary Information}

The online version contains supplementary material available at https://doi. org/10.1186/s12860-020-00326-6.

Additional file 1: Figure 1. Induction of p21+ cells by CPT in BXPC-3, SBLF-7 and SBLF-4 cell lines. Senescence induction by 120 nM Camptothecin for 5 days in a pancreas carcinoma cell line and two skin fibroblasts cell cultures. (A) Representative images of the stained nuclei (dapi), senescent staining (p21) and combined images (merge). (B) Percentage of p21 positive cells of untreated and Camptothecin treated cells. Differences were analyzed by a two-tailed unpaired Mann-Whitney U.

Additional file 2: Figure 2. Prognostic significance of intraepithelial senescent cell density/ $\mathrm{mm}^{2}$ and cell-in-cell phenomena density $/ \mathrm{mm}^{2}$ in Kaplan Meier plots for tumor specific survival. The cut-off values were determined by the ROC curve analysis. This resulted in specific cut off values for each individual analysis. Five-year survival rates are given in brackets after the designation of the corresponding cut-off values. (A) Senescent cell density in tissue micro arrays of biopsies, (B) central tumor (C) invasive tumor front and (D) normal tissue from tumor resection. (E) Cell-incell density in tissue micro arrays of biopsies, (F) central tumor (G) invasive tumor front and $(H)$ normal tissue from tumor resection. Statistical significance was checked by the log-rank test.

Additional file 3: Figure 3.Prognostic significance of intraepithelial senescent cell density/ $\mathrm{mm}^{2}$ and cell-in-cell phenomena density $/ \mathrm{mm}^{2}$ in Kaplan Meier plots for local recurrence free survival. The cut-off values were determined by the ROC curve analysis. This resulted in specific cut off values for each individual analysis. Five-year survival rates are given in brackets after the designation of the corresponding cut-off values. (A) Senescent cell density in tissue micro arrays of biopsies, (B) central tumor (C) invasive tumor front and (D) normal tissue from tumor resection. (E) Cell-in-cell density in tissue micro arrays of biopsies, (F) central tumor (G) invasive tumor front and $(\mathrm{H})$ normal tissue from tumor resection. Statistical significance was checked by the log-rank test.

Additional file 4: Figure 4. Prognostic significance of intraepithelial senescent cell density $/ \mathrm{mm}^{2}$ and cell-in-cell phenomena density $/ \mathrm{mm}^{2}$ in Kaplan Meier plots for metastasis free survival. The cut-off values were determined by the ROC curve analysis. This resulted in specific cut off values for each individual analysis. Five-year survival rates are given in brackets after the designation of the corresponding cut-off values. (A) Senescent cell density in tissue micro arrays of biopsies, (B) central tumor (C) invasive tumor front and (D) normal tissue from tumor resection. (E) Cell-incell density in tissue micro arrays of biopsies, (F) central tumor (G) invasive tumor front and $(\mathrm{H})$ normal tissue from tumor resection. Statistical significance was checked by the log-rank test.

\section{Abbreviations}

SASP: Senescence-associated secretory phenotype; CIC: Cell-in-cell; BEAS2B: Epithelial lung cells; SBLF-4 and SBLF-7: Fibroblast cell lines; CPT: Camptothecin; CTFR: CellTrace Far Red; CTOG: CellTrace Oregon Green; DAPI: 4',6-Diamidin-2-phenylindol; 7AAD: 7-Aminoactinomycin; $\beta$-gal: $\beta$ galactosidase; HMGA2: High-mobility group AT-hook 2 protein; H3K9me3: Histone 3 tri-methylated at the 9th lysine residue; RCT: Radiochemotherapy; TMA: Tissue Micro Array; TRS6: Target removal solutions pH 6; ROC: Receiver operating characteristic analysis

\section{Acknowledgements}

The authors would like to thank Doris Mehler and Elisabeth Müller for excellent technical support during the experiments. The present work was performed in fulfilment of the requirements for obtaining the degree "Dr. med."

\section{Authors' contributions}

Conceptualization, LD, GD and $\mathrm{HN}$; data curation, LD, GD, PF and $\mathrm{HN}$; formal analysis, LD, GD, PF and HN; funding acquisition, FR and LD; Investigation, LD, GD, PF and HN; Methodology, LD, GD, PF and HN; project administration, FR and LD; Resources, FR and LD; Software, LD; supervision LD; Validation, $\mathrm{LD}, \mathrm{GD}, \mathrm{PF}$ and $\mathrm{HN}$; visualization, $\mathrm{LD}, \mathrm{GD} B H M$ and $\mathrm{HN}$; writing - original draft, LD, GD, HM; writing - review \& editing LD, FR, GD, PF, BHM, HM and $\mathrm{HN}$. All authors have contributed to the work and read and approved the manuscript.

\section{Funding}

This research received no external funding. Open Access funding enabled and organized by Projekt DEAL.

\section{Availability of data and materials}

The datasets used and/or analyzed during the current study are available from the corresponding author on reasonable request.

\section{Ethics approval and consent to participate}

All patients signed a written consent form, permitting the analysis of routinely obtained pathologic samples and clinical data for research purposes. The use of formalin-fixed paraffin-embedded material from the Archive of the Institute of Pathology was approved by the Ethics Committee of the Friedrich-Alexander-University of Erlangen-Nuremberg on 24 January 2005.

\section{Consent for publication}

Not applicable.

\section{Competing interests}

The authors declare no conflict of interest.

\section{Author details}

'Department of Radiation Oncology, Universitätsklinikum Erlangen, Friedrich-Alexander-Universität Erlangen-Nürnberg, D-91054 Erlangen, Germany. ${ }^{2}$ Department of Nephropathology, Institute of Pathology, Universitätsklinikum Erlangen, Friedrich-Alexander-Universität Erlangen, Nürnberg, Germany.

Received: 15 May 2020 Accepted: 27 October 2020

Published online: 07 November 2020

\section{References}

1. Galluzzi L, Vitale I, Aaronson SA, Abrams JM, Adam D, Agostinis P, Alnemri ES, Altucci L, Amelio I, Andrews DW, Annicchiarico-Petruzzelli M, Antonov AV, Arama E, Baehrecke EH, Barlev NA, Bazan NG, Bernassola F, Bertrand MJM, Bianchi K, Blagosklonny MV, Blomgren K, Borner C, Boya P, Brenner C, Campanella M, Candi E, Carmona-Gutierrez D, Cecconi F, Chan FK, Chandel NS, Cheng EH, Chipuk JE, Cidlowski JA, Ciechanover A, Cohen GM, Conrad M, Cubillos-Ruiz JR, Czabotar PE, D'Angiolella V, Dawson TM, Dawson VL, De Laurenzi V, De Maria R, Debatin KM, DeBerardinis RJ, Deshmukh M, Di Daniele N, Di Virgilio F, Dixit VM, Dixon SJ, et al. Molecular mechanisms of cell death: recommendations of the nomenclature committee on cell death 2018. Cell Death Differ. 2018;25:486-541. 
2. Appelt AL, Ploen J, Vogelius IR, Bentzen SM, Jakobsen A. Radiation doseresponse model for locally advanced rectal cancer after preoperative chemoradiation therapy. Int J Radiat Oncol Biol Phys. 2013;85:74-80.

3. Bulens P, Couwenberg A, Haustermans K, Debucquoy A, Vandecaveye V, Philippens M, Zhou M, Gevaert O, Intven M. Development and validation of an MRI-based model to predict response to chemoradiotherapy for rectal cancer. Radiother Oncol. 2018;126:437-42.

4. Habr-Gama A, São Julião GP, Fernandez LM, Vailati BB, Andrade A, Araújo SEA, Gama-Rodrigues J, Perez RO. Achieving a complete clinical response after neoadjuvant chemoradiation that does not require surgical resection. Dis Colon Rectum. 2019;62:802-8

5. Prieur A, Peeper DS. Cellular senescence in vivo: a barrier to tumorigenesis Curr Opin Cell Biol. 2008;20:150-5.

6. Kuilman T, Michaloglou C, Mooi WJ, Peeper DS. The essence of senescence. Genes Dev. 2010;24:2463-79.

7. Herranz N, Gil J. Mechanisms and functions of cellular senescence. J Clin Invest. 2018:128:1238-46

8. Rodier F, Campisi J. Four faces of cellular senescence. J Cell Biol. 2011;192: 547-56

9. Chen Z, Cao K, Xia Y, Li Y, Hou Y, Wang L, Li L, Chang L, Li W. Cellular senescence in ionizing radiation (review). Oncol Rep. 2019;42:883-94.

10. Ewald JA, Desotelle JA, Wilding G, Jarrard DF. Therapy-induced senescence in cancer. J Natl Cancer Inst. 2010;102:1536-46.

11. Tabasso AFS, Jones DJL, Jones GDD, Macip S. Radiotherapy-induced senescence and its effects on responses to treatment. Clin Oncol. 2019;31: 283-9.

12. Coppe JP, Desprez PY, Krtolica A, Campisi J. The senescence-associated secretory phenotype: the dark side of tumor suppression. Annu Rev Pathol. 2010:5:99-118.

13. Munoz-Espin D, Serrano M. Cellular senescence: from physiology to pathology. Nat Rev Mol Cell Biol. 2014;15:482-96.

14. Hoenicke L, Zender L. Immune surveillance of senescent cells--biological significance in cancer- and non-cancer pathologies. Carcinogenesis. 2012;33: 1123-6.

15. Xue W, Zender L, Miething C, Dickins RA, Hernando E, Krizhanovsky V, Cordon-Cardo C, Lowe SW. Senescence and tumour clearance is triggered by p53 restoration in murine liver carcinomas. Nature. 2007;445:656-60.

16. Ichimura T, Asseldonk EJ, Humphreys BD, Gunaratnam L, Duffield JS, Bonventre JV. Kidney injury molecule-1 is a phosphatidylserine receptor that confers a phagocytic phenotype on epithelial cells. J Clin Invest. 2008;118: 1657-68.

17. Kolb S, Vranckx R, Huisse MG, Michel JB, Meilhac O. The phosphatidylserine receptor mediates phagocytosis by vascular smooth muscle cells. J Pathol. 2007;212:249-59.

18. Petrovski G, Zahuczky G, Katona K, Vereb G, Martinet W, Nemes Z, Bursch W, Fesus L. Clearance of dying autophagic cells of different origin by professional and non-professional phagocytes. Cell Death Differ. 2007;14: $1117-28$.

19. Schwegler M, Wirsing AM, Dollinger AJ, Abendroth B, Putz F, Fietkau R, Distel LV. Clearance of primary necrotic cells by non-professional phagocytes. Biol Cell. 2015;107:372-87.

20. Abodief TW, Dey P, Al-Hattab O. Cell cannibalism in ductal carcinoma of breast. Cytopathology. 2006;17:304-5.

21. Cano CE, Sandi MJ, Hamidi T, Calvo EL, Turrini O, Bartholin L, Loncle C, Secq V, Garcia S, Lomberk G, Kroemer G, Urrutia R, lovanna JL. Homotypic cell cannibalism, a cell-death process regulated by the nuclear protein 1 opposes to metastasis in pancreatic cancer. EMBO Mol Med. 2012;4:964-79.

22. Fais S, Overholtzer M. Cell-in-cell phenomena in cancer. Nat Rev Cancer. 2018;18:758-66.

23. Gupta K, Dey P. Cell cannibalism: diagnostic marker of malignancy. Diagn Cytopathol. 2003;28:86-7.

24. Lugini L, Matarrese P, Tinari A, Lozupone F, Federici C, lessi E, Gentile M, Luciani F, Parmiani G, Rivoltini L, Malorni W, Fais S. Cannibalism of live lymphocytes by human metastatic but not primary melanoma cells. Cancer Res. 2006;66:3629-38.

25. Schwegler M, Wirsing AM, Schenker HM, Ott L, Ries JM, Buttner-Herold M, Fietkau R, Putz F, Distel LV. Prognostic value of homotypic cell internalization by nonprofessional phagocytic cancer cells. Biomed Res Int 2015;2015:359392.

26. Durgan J, Florey O. Cancer cell cannibalism: multiple triggers emerge for entosis. Biochim Biophys Acta, Mol Cell Res. 2018;1865:831-41.
27. Calcinotto A, Kohli J, Zagato E, Pellegrini L, Demaria M, Alimonti A. Cellular senescence: aging, cancer, and injury. Physiol Rev. 2019;99:1047-78.

28. Li M, You L, Xue J, Lu Y. lonizing radiation-induced cellular senescence in normal, non-transformed cells and the involved DNA damage response: a mini review. Front Pharmacol. 2018;9:522.

29. Yosef R, Pilpel N, Papismadov N, Gal H, Ovadya Y, Vadai E, Miller S, Porat Z, Ben-Dor S, Krizhanovsky V. p21 maintains senescent cell viability under persistent DNA damage response by restraining JNK and caspase signaling. EMBO J. 2017:36:2280-95.

30. Soto-Gamez A, Quax WJ, Demaria M. Regulation of survival networks in senescent cells: from mechanisms to interventions. J Mol Biol. 2019;431:2629-43.

31. Seeberg JC, Loibl M, Moser F, Schwegler M, Buttner-Herold M, Daniel C, Engel FB, Hartmann A, Schlotzer-Schrehardt U, Goppelt-Struebe M, Schellerer V, Naschberger E, Ganzleben I, Heinzerling L, Fietkau R, Distel LV. Non-professional phagocytosis: a general feature of normal tissue cells. Sci Rep. 2019;9:11875.

32. Overholtzer M, Mailleux AA, Mouneimne G, Normand G, Schnitt SJ, King RW, Cibas ES, Brugge JS. A nonapoptotic cell death process, entosis, that occurs by cell-in-cell invasion. Cell. 2007;131:966-79.

33. Huang $H$, Chen A, Wang T, Wang M, Ning X, He M, Hu Y, Yuan L, Li S, Wang Q, Liu H, Chen Z, Ren J, Sun Q. Detecting cell-in-cell structures in human tumor samples by E-cadherin/CD68/CD45 triple staining. Oncotarget. 2015;6:20278-87.

34. Alok M, Singh S, Swarn K, al. e. Cell cannibalism as an indicator of anaplasia and tumor aggresiveness in carinoma breast. J Adv Res Biol Sci. 2013;5:286-9.

35. Kojima S, Sekine H, Fukui I, Ohshima H. Clinical significance of cannibalism in urinary cytology of bladder cancer. Acta Cytol. 1998;42:1365-9.

36. Schenker H, Buttner-Herold M, Fietkau R, Distel LV. Cell-in-cell structures are more potent predictors of outcome than senescence or apoptosis in head and neck squamous cell carcinomas. Radiat Oncol. 2017;12:21.

37. Jain M, Saawarn S, Gupta A, Ashok S, Mhaske S, Khan S. Assessment of tumor cell cannibalism as a predictor of oral squamous cell carcinoma - a histopathologic correlation. Gulf J Oncol. 2017;23:52-6.

38. Mackay HL, Moore D, Hall C, Birkbak NJ, Jamal-Hanjani M, Karim SA, Phatak VM, Pinon L, Morton JP, Swanton C, Le Quesne J, Muller PAJ. Genomic instability in mutant p53 cancer cells upon entotic engulfment. Nat Commun. 2018:9:3070.

39. Durgan J, Tseng YY, Hamann JC, Domart MC, Collinson L, Hall A, Overholtzer M, Florey O. Mitosis can drive cell cannibalism through entosis. Elife. 2017;6.

40. Hamann JC, Surcel A, Chen R, Teragawa C, Albeck JG, Robinson DN, Overholtzer M. Entosis is induced by glucose starvation. Cell Rep. 2017;20:201-10.

41. Krajcovic M, Krishna S, Akkari L, Joyce JA, Overholtzer M. mTOR regulates phagosome and entotic vacuole fission. Mol Biol Cell. 2013;24:3736-45.

42. Krishna S, Overholtzer M. Mechanisms and consequences of entosis. Cell Mol Life Sci. 2016;73:2379-86.

43. Li W, Baker NE. Engulfment is required for cell competition. Cell. 2007;129: 1215-25.

44. Bavik C, Coleman I, Dean JP, Knudsen B, Plymate S, Nelson PS. The gene expression program of prostate fibroblast senescence modulates neoplastic epithelial cell proliferation through paracrine mechanisms. Cancer Res. 2006; 66:794-802.

45. Coppe JP, Kauser K, Campisi J, Beausejour CM. Secretion of vascular endothelial growth factor by primary human fibroblasts at senescence. $J$ Biol Chem. 2006;281:29568-74.

46. Parrinello S, Coppe JP, Krtolica A, Campisi J. Stromal-epithelial interactions in aging and cancer: senescent fibroblasts alter epithelial cell differentiation. J Cell Sci. 2005;118:485-96.

47. Krtolica A, Parrinello S, Lockett S, Desprez PY, Campisi J. Senescent fibroblasts promote epithelial cell growth and tumorigenesis: a link between cancer and aging. Proc Natl Acad Sci U S A. 2001;98:12072-7.

48. Gani C, Zips D. [Time interval between neoadjuvant radiochemotherapy and surgery in rectal cancer : no impact on the pathologic complete response rate?]. Strahlenther Onkol 2017; 193:91-92.

49. Jager T, Neureiter D, Fallaha M, Schredl P, Kiesslich T, Urbas R, Klieser E, Holzinger J, Sedlmayer F, Emmanuel K, Dinnewitzer A. The potential predictive value of tumor budding for neoadjuvant chemoradiotherapy response in locally advanced rectal cancer. Strahlenther Onkol. 2018;194:991-1006.

\section{Publisher's Note}

Springer Nature remains neutral with regard to jurisdictional claims in published maps and institutional affiliations. 